\title{
Głód w KL Stutthof
}

\author{
Hunger in KL Stutthof
}

\section{Summary}

A history of the concentration camps is related with huge hunger. It was a hunger that was constantly in the psyche and managed the life of the prisoners. Food rations were calculated to let the prisoner survive in the camp for a maximum three months.

The food was monotonous and defective. Based on the memories of the prisoners and reports of the Soviet Commission, it is known that the food was prepared from the worst quality of products, e.g. bread was on the basis of flour mixed with sawdust, what totally changed the structure, the loaf was clayey, often moldy, and that was the main cause of bloody diarrhea, cheese or marmalade were contaminated or spoiled, the same situation was with the other products.

Prisoners tried to fight for each additional portion of food. Prisoners stole food, and that was severely punished - in many cases food was taken away for few days, what accelerated their encounter with death.

As a result of prolonged hunger, the body has undergone irreversible changes. The first stage of the disease is a state of nutritional deficiency, which is mainly characterized by losing weight, because the body uses its own fat stores (socalled compensation). The second stage is hunger. The body exhausts its own nutritional and energy reserves, and after using them consumes protein bodies, causing tissue damage.

In my article, I would like to explain how hunger affected the body. What happened to organism? What happened to the psyche? Which group of prisoners was the most vulnerable to the destruction of the body? The analysis is based on the source material kept in the Archives of Museum Stutthof in Sztutowo and specialist literature.

Słowa kluczowe: Stutthof, obozy koncentracyjne, głód, choroba głodowa, normy żywieniowe, zmiany w psychice, zmiany w organizmie

Keywords: Stutthof, concentration camps, hunger, nutritional norms, psychological changes, changes in the organism 
Temat głodu występującego w obozach był wielokrotnie poruszany w licznych powojennych publikacjach lekarskich oraz monografiach poświęconych tematyce obozów koncentracyjnych ${ }^{1}$. Jednak niezwykle newralgicznym źródłem są relacje i wspomnienia osadzonych, którzy przeżyli obozową katorgę, oraz zachowana niemiecka dokumentacja obozowego szpitala². Głód w KL Stutthof doczekał się kilku krótkich podsumowań w zbiorowych monografiach naukowych wydanych przez $\mathrm{Mu}$ zeum Stutthof w Sztutowie ${ }^{3}$. Niniejszy artykuł powstał na bazie specjalistycznych artykułów zawartych w „Przeglądzie Lekarskim - Oświęcim”, publikacji naukowych dotyczących obozu Stutthof oraz relacji więźniów.

\section{Obóz Stutthof}

Obóz koncentracyjny Stutthof został założony 2 września 1939 r. w pobliżu wsi Sztutowo, znajdującej się $36 \mathrm{~km}$ od Gdańska. Już tego dnia przysłano do niego pierwszy transport, liczący 150 osób ${ }^{4}$. Od jesieni 1939 r. Stutthof nosił nazwę Obozu Jeńców Cywilnych Stutthof. 1 października 1941 r. Stutthof został przekształcony w obóz pracy wychowawczej, podporządkowany urzędowi Gestapo w Gdańsku, a 7 stycznia 1942 r. zyskał status państwowego obozu koncentracyjnego i od tej pory podlegał centralnym władzom SS w Berlinie.

Pierwszym komendantem był SS-Hauptsturmführer Max Pauly, który zarządzał całym obozem od dnia utworzenia aż do 31 sierpnia 1942 r., kiedy to został przeniesiony do KL Neuengamme. Drugim komendantem został SS-Sturmbahnführer Paul Werner Hoppe, oficer SS-Totenkopfverbände, który we wcześniejszym okresie był członkiem załogi KL Dachau.

${ }^{1}$ Odsyłam czytelnika do „Przeglądu Lekarskiego - Oświęcim”, gdzie można zapoznać się z takimi artykułami, jak: Z. Ryn, S. Kłodziński, Głód w obozie koncentracyjnym (1984); Psychopatologia głodu w obozie koncentracyjnym (1985); Na granicy życia i śmierci. Studium obozowego muzułmaństwa (1983); H. Münch, Głód i czas przeżycia w obozie oświęcimskim (1967); J. Kowalczykowa, Choroba głodowa w obozie koncentracyjnym w Oświęcimiu (1961).

2 Archiwum Muzeum Stutthof w Sztutowie posiada najliczniejszy i najlepiej zachowany zbiór dokumentacji na tle pozostałych muzeów martyrologii. Akta byłej kancelarii obozu, tworzące zespół Konzentrationslager Stutthof, powstały w latach 1939-1945 i liczą 67828 j.a. o wielkości 116 mb. Kolejnym cennym zbiorem są Relacje i Wspomnienia, których zebrano łącznie ok. 650 rękopisów, co daje łącznie 27 tomów.

${ }_{3}$ Zagadnienie głodu poruszali w Zeszytach Muzealnych m.in.: Miron Kłusak (1976), Mirosław Gliński (1976), Maria Elżbieta Jezierska (1987); w monografii naukowej Stutthof hitlerowski obóz koncentracyjny (Warszawa 1988) o wyżywieniu pisała Elżbieta Grot.

4 J. Grabowska-Chałka, Przewodnik. Informator historyczny, Gdańsk-Sztutowo 2014, s. 19. 
Wyzwolenie miało miejsce 9 maja 1945 r. Szacuje się, że w ciągu pięciu lat funkcjonowania KL Stutthof zarejestrowano ok. 110000 więźniów, z czego aż ok. 65000 poniosło w nim śmierć wskutek wykańczającej pracy, ekstremalnych warunków bytowych, niedostatecznej opieki lekarskiej, eksperymentów medycznych oraz morderczych ewakuacji ${ }^{5}$. Muzeum zostało utworzone 12 marca 1962 r. uchwała Prezydium Wojewódzkiej Rady Narodowej w Gdańsku.

\section{Wyżywienie w obozie Stutthof}

Normy wyżywienia więźniów określały władze danego obozu. Niemal w każdym lagrze ustalone porcje żywnościowe były niewystarczające do przeżycia, przede wszystkim z powodu ich jakości, jak i pracy, którą więźniowie wykonywali ponad siły, często po 10-12 godzin dziennie.

Do utrzymania życia w całkowitym spoczynku potrzeba $1500 \mathrm{kcal}$ na dobe, jednak wszelka praca wymaga dodatkowego nakładu energii, dla przykładu: samo utrzymywanie pozycji pionowej to potrzeba dostarczenia dodatkowych $300 \mathrm{kcal}^{6}$. W przypadku ciężkiej pracy fizycznej należy przyjmować jako normę dzienną 4000-5000 kcal7. Władze Stutthofu ustaliły normę pożywienia dla więźniów na $1800 \mathrm{kcal}^{8}$, jednak w rzeczywistości więźniowie otrzymywali pokarmy o wartości odżywczej w przedziale od 1000 do $1300 \mathrm{kcal}$, czyli dawkę mniejszą niż ilość konieczna dla podtrzymania życia w stanie spoczynku. Gdy przez dłuższy czas nie można uzyskać pokarmu, zapotrzebowanie energii pokrywa rezerwa, czyli zapasy tłuszczowe ustroju. Głodzenie więźniów było zaplanowane i miało ich doprowadzić w krótkim czasie do śmierci głodowej. Racje żywnościowe były rozpisane w taki sposób, by więzień mógł funkcjonować w obozie maksymalnie trzy miesiące ${ }^{9}$.

\footnotetext{
${ }^{5}$ A. Coradello, Co się działo w Stutthofie, Warszawa 2011, s. 72.

${ }^{6} \mathrm{H}$. Münch, Głód i czas przeżycia w obozie oświęcimskim, „Przegląd Lekarski Oświęcim” 1967, nr 1, s. 79.

7 Tamże, s. 79.

${ }^{8}$ K. Ciechanowski, B. Chrzanowski, D. Drywa, Stutthof hitlerowski obóz koncentracyjny, Warszawa 1988, s. 194-195.

${ }_{9}$ W 1947 r. wykonano badania mające na celu sprawdzenie, jaki wpływ na szczury będzie miało wyżywienie, które podawano więźniom w obozach. Po upływie trzech miesięcy pojawił się zespół zmian charakterystycznych dla choroby głodowej. Dokładnie tak, jak u ludzi (zob. K. Okoniewska, Zbrodniczy medycy. Lekarze z Auschwitz, Łódź 2017).
} 


\section{Racje żywnościowe i wydawane posiłki}

Gdy rozpatruje się kwestię ustalonych w obozach racji żywnościowych, należy zdawać sobie sprawę z różnic zachodzących między porcjami przewidzianymi $\mathrm{w}$ jadłospisie, wydawanymi $\mathrm{w}$ magazynie kuchennym a tymi, które ostatecznie docierały do więźnia. 7 stycznia 1944 r. władze obozu wydały dokument, który określał, jaka ilość żywności (dosł. zestawy stołowe) powinna zostać przydzielona więźniom. Na jedną osobę miało w tygodniu przypadać:

Tab. 1. Tygodniowy przydział żywności na jedną osobę w KL Stutthof

\begin{tabular}{|l|r|r|}
\hline \multicolumn{1}{|c|}{ Wydawany produkt } & Więźniowie & Ludność cywilna* \\
\hline Mało wartościowe mięso & $200 \mathrm{~g}$ & $250 \mathrm{~g}$ \\
\hline Masło & - & $125 \mathrm{~g}$ \\
\hline Margaryna & $182.5 \mathrm{~g}$ & $50 \mathrm{~g}$ \\
\hline Smalec & - & $22.5 \mathrm{~g}$ \\
\hline Oleje jadalne & - & $12.5 \mathrm{~g}$ \\
\hline Ser topiony & $50 \mathrm{~g}$ & ser $30 \mathrm{~g}$ \\
\hline Twaróg & - & $30 \mathrm{~g}$ \\
\hline Marmolada & $100 \mathrm{~g}$ & $175 \mathrm{~g}$ \\
\hline Chleb & $2525 \mathrm{~g}$ & $1675 \mathrm{~g}$ \\
\hline Ciasto pszenne & - & $750 \mathrm{~g}$ \\
\hline Przyprawy & $165 \mathrm{~g}$ & $150 \mathrm{~g}$ \\
\hline Mąka do zupy & $135 \mathrm{~g}$ & - \\
\hline Cukier & $80 \mathrm{~g}$ & $225 \mathrm{~g}$ \\
\hline Kawa zbożowa & $63 \mathrm{~g}$ & $63 \mathrm{~g}$ \\
\hline Ziemniaki & $3500 \mathrm{~g}$ & $3000 \mathrm{~g}$ \\
\hline Warzywa & $3900 \mathrm{~g}$ & $?$ \\
\hline Brukiew & $2000 \mathrm{~g}$ & $?$ \\
\hline Mleko (wg zalecenia) & $1 / 4 \mathrm{l}$ & 11 \\
\hline Kasza & $30 \mathrm{~g}$ & - \\
\hline $\begin{array}{l}\text { Chleb jako substytut } \\
\text { ziemniaków }\end{array}$ & - & $150 \mathrm{~g}$ \\
\hline
\end{tabular}

* Na terenie obozu przebywała także ludność cywilna.

Źródło: Archiwum Muzeum Stutthof, Zaopatrzenie kuchni w środki żywnościowe. Korespondencja, rozliczenia, sygn. I-IVI-2, s. 24.

Na podstawie powyższej tabeli można wywnioskować, że jedynym źródłem tłuszczu była margaryna, a cukier otrzymywano w niewielkiej ilości (z relacji więźniów wynika, że były też takie okresy w obozie, gdy nie otrzymywano go w ogóle). Mleko podawane było tylko według zalecenia i wówczas więzień dostawał $250 \mathrm{ml}$ na tydzień. Pro- 
duktem wydawanym w największej ilości były warzywa i ziemniaki. Mięso jako cenne źródło białka, żelaza i tłuszczu powinno być wręcz podstawowym posiłkiem u ciężko pracującej osoby, jednakże w obozach było rozdawane rzadko i w niedostatecznych ilościach - w tabeli znajduje się informacja, że na więźnia przypada w tygodniu $200 \mathrm{~g}$ mało wartościowego mięsa. W KL Stutthof nie przeprowadzano kontroli sanitarnej pożywienia ${ }^{10}$.

W dokumencie zawarto ponadto informacje dotyczące dodatkowych racji żywnościowych dla osób ciężko i długo pracujących (tzw. zulagi).

Tab. 2. Tygodniowy przydział dodatków dla ciężko pracujących na jedną osobę w KL Stutthof

\begin{tabular}{|l|c|c|}
\hline \multicolumn{3}{|c|}{ Dodatek dla ciężko pracujących } \\
\hline \multicolumn{1}{|c|}{ produkt dodatkowy } & więźniowie & ludność cywilna \\
\hline Mało wartościowe mięso & $280 \mathrm{~g}$ & $350 \mathrm{~g}$ \\
\hline Margaryna & $100 \mathrm{~g}$ & - \\
\hline Tłuszcz & - & $40 \mathrm{~g}$ \\
\hline Boczek lub smalec & - & $63 \mathrm{~g}$ \\
\hline Chleb & $1400 \mathrm{~g}$ & $1400 \mathrm{~g}$ \\
\hline
\end{tabular}

Źródło: na podstawie dokumentu znajdującego się w AMS, Zaopatrzenie kuchni w środki żywnościowe. Korespondencja, rozliczenia, sygn. I-IVI-2, s. 24.

Tab. 3. Tygodniowy przydzial dodatków dla długo pracujących na jedną osobę w KL Stutthof

\begin{tabular}{|l|c|c|}
\hline \multicolumn{3}{|c|}{ Dodatek dla długo pracujących } \\
\hline \multicolumn{1}{|c|}{ produkt dodatkowy } & więźniowie & ludność cywilna \\
\hline $\begin{array}{l}\text { Mało wartościowe } \\
\text { mięso }\end{array}$ & $140 \mathrm{~g}$ & $200 \mathrm{~g}$ \\
\hline Margaryna & $20 \mathrm{~g}$ & $20 \mathrm{~g}$ \\
\hline Chleb & $600 \mathrm{~g}$ & $700 \mathrm{~g}$ \\
\hline
\end{tabular}

Źródło: na podstawie dokumentu znajdującego się w AMS, Zaopatrzenie kuchni w środki żywnościowe. Korespondencja, rozliczenia, sygn. I-IVI-2, s. 24.

W przypadku obu grup w dalszym ciągu porcje jedzenia były niedostateczne. Dodatkiem dla ciężko pracujących było $280 \mathrm{~g}$ mało war-

${ }^{10} \mathrm{~W}$ obozach, w których przeprowadzono kontrolę sanitarną pożywienia, otrzymywane wyniki wskazywały, że mięso pochodziło wg klasyfikacji berlińskiej II nr 7 ze starej, wychudzonej krowy i znajdowało się w stadium rozkładu. Por. K. Okoniewska, dz. cyt., s. 67. 
tościowego mięsa, $100 \mathrm{~g}$ margaryny oraz $1400 \mathrm{~g}$ chleba. Osoby długo pracujące (np. rzemieślnicy) otrzymywały z kolei 140 g małowartościowego mięsa, $20 \mathrm{~g}$ margaryny i $600 \mathrm{~g}^{\text {chleba }}{ }^{11}$.

Powyższe dane wskazują, że pokarm był jednostajny, niepełnowartościowy, wydawany w niewystarczającej ilości. Opierając się na relacjach oraz raporcie Komisji Radzieckiej, wiadomo, że jedzenie było przygotowywane z najgorszej jakości produktów, np. chleb wyrabiano na bazie mąki wymieszanej z trocinami drzewnymi, co miało wpływ na jego strukturę, bochenek był gliniasty, często też spleśniały, a dla organizmu ciężkostrawny i powodujący krwawe biegunki, dodatki w postaci serka czy marmolady bywały zanieczyszczone lub zepsute, podobnie jak pozostałe produkty.

Jak żywienie wyglądało w praktyce? Więźniowie ustawiali się przed blokiem w kolejkę, podczas przechodzenia przez drzwi byli uderzani przez SS-manów kolbami i w pośpiechu odbierali swoje porcje. Posiłki musiały zostać zjedzone szybko, ponieważ przy kolejnych drzwiach odbierano menażki przy jednoczesnym biciu. Przyczyniało się to do rozlewania zupy i utraty części, i tak już skąpej, racji. Zdarzały się sytuacje, że po wydaniu porcji dolewek, gdy kotły stały opróżnione, więźniowie rzucali się na nie i wybierali palcami resztki lub wkładali do środka głowy i wylizywali wnętrze kotła ${ }^{12}$. Od $1943 \mathrm{r}$. więźniowie jedli przy stołach.

Zasadniczym pożywieniem był bochen chleba o wadze ok. $1,8 \mathrm{~kg}$ dzielony początkowo na 4 więźniów ${ }^{13}$, a w późniejszym okresie na 10 , a nawet 12 osób $^{14}$. Osadzeni otrzymywali trzy posiłki:

- Śniadanie: kubek wodnistego napoju bez cukru, kromka chleba, margaryna lub marmolada z brukwi.

- Obiad: miska zupy bez tłuszczu i przypraw ugotowana z nadgniłych lub przemarzniętych warzyw, takich jak marchew, liście kapusty czy buraki pastewne. Nieobrane buraki wsypywano w całości do kotła, co w efekcie dawało gęstą, czarną zawiesinę. Do potraw obiadowych nie dodawano soli.

Były więzień Jan Strycharczyk (numer 7613) w swojej relacji tak skomentował obiady w obozie: „Smutne to były chwile, kiedy po obiedzie był człowiek taki głodny jak przed obiadem, bo w zupie nie było nic gęstego, a jeżeli czasami wpadł jeden ziemniak albo też malutki kawałe-

11 Archiwum Muzeum Stutthof (dalej AMS), Verwaltung, Zaopatrzenie kuchni w środki żywnościowe. Korespondencja, rozliczenia, sygn. I-IVI-2, s. 24.

${ }_{12}$ AMS, Relacje i Wspomnienia t. 5, relacja Jana Strycharczyka, s. 264.

${ }_{13}$ AMS, Relacje i Wspomnienia t. 12, relacja Franciszka Guzińskiego, s. 120.

14 AMS, Relacje i Wspomnienia t. 4, relacja Romana Olszewskiego, s. 182. 
czek mięsa, to radość nieopisana i przed kolegami się chwalił, że miał w zupie ziemniaka"15.

Irena Wrońska, była więźniarka KL Stutthof, w swojej relacji spisała, że zupę noszono w baniakach już od wczesnych godzin rannych i wlewano do pojemnika $\mathrm{z}$ drewna, który stał na placu pomiędzy barakami. Jako że nie był przykrywany, zawsze było w nim dużo piachu i na zupie tworzył się z niego kożuch ${ }^{16}$.

- Kolacja: kubek wodnistego napoju, kromka chleba, trochę marmolady z brukwi lub topionego sera. Wędlinę, przeważnie nadpsutą, wydawano w niedzielę, w ilości 7-8 dkg. Zdarzało się, że na kolacje podawano kartofle $\mathrm{z}$ kwaszonym mlekiem lub smażony makaron ${ }^{17}$. Nowo narodzonym w obozie dzieciom władze KL wydzieliły $1 / 4$ litra chudego mleka, odciąganego codziennie. Więźniowie chętnie służyli pomocą i starali się o pokarm dla nich, przykładowo zdobywali dodatkowe porcje mleka z obory obozowej SS ${ }^{18}$.

Spośród wszystkich więźniów najmniejsze porcje otrzymywali Żydzi. Przydzielano im: ok. 150 g chleba, 10 g marmolady lub 20 g margaryny, dwa razy po pół litra kawy i maksymalnie 3/4 litra zupy, jednak bardzo często zdarzało się, że te i tak maleńkie porcje (wartość kaloryczna nie przekraczała $1000 \mathrm{kcal}$ ) były jeszcze mniejsze.

Cyryla Elberg, Żydówka będąca więźniarką KL Stutthof (numer 83 416), w swej relacji wspominała: „W Stutthofie dostawałyśmy 17 czy $18 \mathrm{dkg}$ chleba i na obiad około pół litra zupy, zupełnie wodnistej”"

W latach 1940-1942, gdy w obozie panował głód, zdarzało się, że pokarmy wydawano w jeszcze mniejszych ilościach, np. kromka chleba ważyła średnio ok. $100 \mathrm{~g}^{20}$, margaryna ok. 15-25 g, zupa kartoflana lub z buraków (czasami także z koniny) od 3/4 do pół litra. Rano i wieczorem przypadało na głowę po pół litra kawy bez cukru.

Warto w tym miejscu omówić krótko transport więźniów rosyjskich, który przybył do KL Stutthof w dniach 5-7 listopada $1942 \mathrm{r}$. Na podstawie zachowanego wykazu więźniów z podaniem wagi ciała w dniu przybycia do obozu i ponownym ważeniu w dniu 24 listopada łatwo zauważyć, jaki ogromny wpływ na wagę ciała miał pobyt w lagrze w dość krótkim czasie, dla przykładu: Gorecki Johann ważył

\footnotetext{
${ }^{15}$ AMS, Relacje i Wspomnienia t. 5, relacja Jana Strycharczyka, s. 239.

${ }^{16}$ AMS, Relacje i Wspomnienia t. 16, relacja Ireny Wrońskiej, s. 49.

${ }_{17}$ AMS, Relacje i Wspomnienia t. 5, relacja Bronisława Pawlikowskiego, s. 145.

${ }_{18}$ AMS, Relacje i Wspomnienia t. 16, relacja Stanisławy Kłosińskiej, s. 46.

${ }^{19}$ AMS, Relacje i Wspomnienia t. 6, relacja Cyryli Elberg, s. 19.

${ }^{20}$ Chleb wydawano dwa razy dziennie, zatem łącznie za dnia więzień otrzymywał
} ok. 200 g chleba. 
początkowo $70 \mathrm{~kg}$, a niespełna trzy tygodnie później jedynie $59 \mathrm{~kg}$, Zwara Aloisius $75 \mathrm{~kg} / 61 \mathrm{~kg}$; Momontow Wieczysław 72 kg/57 kg, Moros Wladimir $73 / 56 \mathrm{~kg}$, Mich Alexej $80 \mathrm{~kg} / 57 \mathrm{~kg}^{21}$. Także w relacjach więźniów często można odnaleźć informacje odnośnie wagi ich ciała: dla przykładu Józef Zieliński (były więzień numer 24 204) podczas przesłuchiwania wyznał, że pod koniec swojego kilkumiesięcznego pobytu w obozie ważył $46 \mathrm{~kg}^{22}$, a z kolei inny więzień - Jerzy Nowicki (były więzień numer 45 032) zeznał, że został oswobodzony w stanie agonalnym, a ważył jedynie $29 \mathrm{~kg}^{23}$.

Od lata 1943 r. z osób słabych, wycieńczonych i wygłodzonych tworzono regularnie oddziały, które umieszczano w specjalnie utworzonym bloku. W 1944 r. do obozu przybył nowy lekarz SS, który nakazał stosować wobec nich specjalny system leczenia. Polecił zmniejszyć wyżywienie z $1 / 2$ do $1 / 4$ porcji. Niektórzy więźniowie nic nie otrzymywali do jedzenia. Jego zdaniem po zmniejszeniu racji żywnościowych: „pojawia się wola życia i zdrowieją, a jeśli ktoś z nich umiera, to jest jego własna sprawa"24.

Na podstawie licznych relacji można wyciągnąć wniosek, że SSmani lubili robić sobie żarty z wygłodzonych więźniów. Jednemu z więźniów regularnie podrzucali szuflę surowych ryb i z rozbawieniem obserwowali, jak spożywał je na surowo. $Z$ czasem zaczęli wystrzeliwać dla niego wrony, które jadł w taki sam sposób. Były też grupy więźniów, które idąc przez pola do pracy wyrywały głąby po kapuście i je spożywały, mimo tego że było to karane biciem ${ }^{25}$. Żydówki oddawały się w zamian za kawałek chleba ${ }^{26}$, więźniowie wyjadali klej stolarski ${ }^{27}$, a jeśli znaleziono paski skórzane od nart, to gotowano z nich zupę ${ }^{28}$. Zdarzały się też sytuacje, kiedy więźniowie włamywali się do budynku psiarni i kradli jedzenie przeznaczone dla czworonogów.

Od 1943 r. można było otrzymywać paczki żywnościowe. Początkowo ich maksymalna waga mogła wynosić $2 \mathrm{~kg}$, po czym została

${ }^{21}$ AMS, Lagerarzt, Wykaz więźniów z podaniem wagi ciała $w$ dniu przybycia do obozu oraz w dniu 24.11.1942 r., I-VB-12, s. 1-6.

${ }^{22}$ AMS, Relacje i Wspomnienia t. 12, relacja Józefa Zielińskiego, s. 90.

${ }^{23}$ AMS, Relacje i Wspomnienia t. 12, relacja Jerzego Nowickiego, s. 78.

${ }_{24}$ AMS, Zbiory, Tłumaczenie dokumentów nadesłanych przez prokurature ZSRR dot. zbrodni popetnionych w KL Stutthof, sygn. Z-V-24, s. 77.

${ }^{25}$ AMS, Relacje i Wspomnienia t. 17, relacja Adama Mirowskiego, s. 105.

${ }^{26}$ AMS, Zbiory, Ttumaczenie dokumentów nadesłanych przez prokurature ZSRR dot. zbrodni popetnionych w KL Stutthof, sygn. Z-V-24,s. 80.

${ }^{27}$ AMS, Relacje i Wspomnienia t. 4, relacja Romana Olszewskiego, s. 182.

${ }_{28}$ AMS, Relacje i Wspomnienia t. 2, relacja Zygmunta Kwapisza, s. 5. 
zmniejszona do $1 \mathrm{~kg}$, a następnie, w związku z deficytem żywności, w latach 1944-1945 wzrosła do nieograniczonej wielkości. Większość zawartości paczki była zabierana przez blokowego lub SS-mana. Niemcy wybierali z paczek wszystko, co mogli, oddawali pokrojony na drobne części chleb, a lepsze artykuły żywnościowe w ogóle nie dochodziły do więźniów ${ }^{29}$. Na poczcie zdarzały się przypadki paczek $\mathrm{z}$ oderwanym adresem i zniszczonym opakowaniem, w takiej sytuacji wstrzymywano wysyłkę i jej zawartość pocztowcy dzielili między siebie. $Z$ czasem celowo uszkadzano paczki bez mankamentów, zwłaszcza te najobfitsze. Paczki dla więźniów zmarłych bądź przeniesionych do innych obozów nie były zwracane i od tej pory znajdowały się $\mathrm{w}$ rękach sekretarza, który najlepsze produkty zatrzymywał dla siebie, a chleb rozdawał więźniom ${ }^{30}$. Żydzi byli najbardziej okradaną z żywności grupą. Więźniowie, którzy otrzymywali paczki, starali się im pomóc. Ci, którzy nie otrzymywali ich w ogóle, byli jednak z reguły skazani na obozowe wyżywienie i głodówkę. Zdarzało się, że zjadano koty i psy, odnotowano też kilka przypadków kanibalizmu: „W styczniu 1942 r. zdarzyło się na izbie, gdzie większość była Rosjan, którzy nie mieli żadnej pomocy, że jeden zmarł, a obok niego leżący wykroił nożem kawał uda i zjadł. Rano zgłoszono esesmanowi, a ten przywołał tego więźnia do siebie i spytał, czy on to zrobił. Odpowiedział, że tak. A czy mu to smakowało. Odpowiedział - tak. I czy by jeszcze coś takiego zrobił. Odpowiedział, że jeżeli by się nadarzyła okazja, to z głodu zawsze zrobi. Esesman kazał zrobić drewniana tablicę. Namalowali «Menschenfresser» (ludożerca) i powiesili mu jedną na piersi, a drugą na plecy. Tak chodził po placu obozowym przez dwa dni, a potem go zabili" 31 .

15 maja 1943 r. szef SS-WHVA Oswald Pohl wprowadził system premiowania więźniów, którzy wydajnie pracowali. Instrumentami podwyższającymi wydajność pracy miały być: złagodzenie odbywania kary w obozie, dodatki żywnościowe, premie pieniężne, przydziały wyrobów tytoniowych i wizyty w obozowym domu publicznym. Wysokość premii była zależna od wydajności i nie mogła być niższa niż 0,5 RM i wyższa niż $4 \mathrm{RM}^{32}$. Premie przyznawano w postaci bonów,

\footnotetext{
${ }^{29}$ AMS, Relacje i Wspomnienia t. 17, relacja Teofilii Białowąs, s. 6.

${ }^{30}$ AMS, Zbiory, Tłumaczenie dokumentów nadesłanych przez prokuraturę ZSRR dot. zbrodni popetnionych w KL Stutthof, sygn. Z-V-24, s. 73-74.

${ }^{31}$ AMS, Relacje i Wspomnienia t. 5, relacja Jana Strycharczyka, s. 261.

${ }^{32}$ M. Orski, Niewolnicza praca więźniów obozu koncentracyjnego Stutthof $w$ latach 1939-1945. Organizacja pracy i metody eksploatacji sity roboczej, Gdańsk 1999, s. 235.
} 
tzw. Prämienschein. W kantynie obozowej można było nabyć za nie m.in.: wodę mineralną, buraki w occie, surowe warzywa, kiszoną kapustę i chleb. W skali całego obozu nie rozwiązywało to jednak nawet częściowo problemu położenia więźniów. Sytuacje, kiedy to wybór produktów był zbyt ubogi bądź ilość zupełnie niewystarczająca, sprawiały, że premiowanie nie osiągnęło zamierzonego skutku. Warto też wspomnieć, że komendant obozu Paul Werner Hoppe zarządził zwiększenie racji żywnościowych, co także było związane z zapotrzebowaniem rąk do pracy w zakładach przemysłowych. Więźniowie dostawali wówczas litr zupy o gęstszej konsystencji i z większą ilością marchwi. Od $1944 \mathrm{r}$. nawet dwa razy w tygodniu gotowano na obiad kaszę lub zupę grochową. Niestety, przywileje te nie dotyczyły Żydów, którym w ciągu ostatnich ośmiu miesięcy funkcjonowania obozu nie rozdawano chleba w ogóle ${ }^{33}$.

\section{Kuchnia obozowa}

Kuchnia obozowa wraz z magazynem żywności została wybudowana w centrum lagru. Znajdowało się w niej 50 kotłów kuchennych $\mathrm{i}$ istniało też osobne pomieszczenie, w którym obierano jarzyny. Obóz posiadał własną rzeźnię, która zaopatrywała kuchnię dla SS w mięso. W latach 1942-1943, kiedy budowano część zwaną Nowym Obozem, w baraku 16 stworzono tymczasową kuchnię z podręcznym magazynem żywnościowym. W związku z tym budynek starej kuchni przemieniono na pralnię, gdzie od tej pory pracowało jedno z najcięższych komand.

Kuchnia więźniarska przygotowywała posiłki według zapotrzebowania złożonego na podstawie meldunku Rapportabteilung (niem. biuro ewidencji obozu). Praca w kuchni zaczynała się o pierwszej w nocy. W związku z tym, że Żydówki nie pracowały, jako pierwsze otrzymywały kawę. Dla pozostałych osadzonych kawę szykowano rano: rozlewano ją w termosy i pojemniki. Pierwsza partia obiadu przygotowywana była ok. godziny czwartej nad ranem. W kuchni znajdującej się na Nowym Obozie były dwa kotły o objętości 500 litrów i osiem kotłów 300-litrowych. Za jednym razem gotowano 3800 litrów zupy. W 1944 r., kiedy do KL Stutthof przybyły Żydówki, a stan obozu wynosił 28-30 tys. więźniów, gotowało się wówczas 40-45 tys. litrów zupy ${ }^{34}$. Do obierania ziemniaków zatrudniano ludzi najsłabszych, przeważnie

${ }^{33}$ AMS, Zbiory, Ttumaczenie dokumentów nadesłanych przez prokuraturę ZSRR dot. zbrodni popetnionych w KL Stutthof, sygn. Z-V-24, s. 26.

${ }^{34}$ AMS, Relacje i Wspomnienia t. 12, relacja Jana Kroplewskiego, s. 139-140. 
z obrzękami, zaniedbanych, brudnych, nierzadko z ropiejącymi palcami. Ziemniaki niedostatecznie obrane i obmyte wrzucano do kotła, a podawano przeważnie niedogotowane. Kuchnię zamykano w późnych godzinach wieczornych. $\mathrm{Z}$ czasem ustawiono przed barakami duże drewniane koryta bez pokrycia. Wlewano do nich zupę obiadową i rozdzielano pomiędzy więźniów. Deszcz, śnieg, piasek, brud wpadały do koryt i stawały się domieszką obiadu.

W 1944 r. w ramach planowanej rozbudowy obozu powstała Nowa Kuchnia. Przeznaczono ją do wydawania posiłków dla ok. 100000 więźniów, jednak ostatecznie pełniła zupełnie inne funkcje, gdyż początkowo służyła jako magazyn, a od końca sierpnia była miejscem zakwaterowania grupy więźniów żydowskich.

Kuchnia dla wachmanów i oficerów wyższych mieściła się w budynku komendantury obozu na parterze, a SS-mani spożywali początkowo posiłki w bloku I na terenie obozu. Do obowiązków pomocy kuchennej stworzonej z wybranej grupy osadzonych należało przede wszystkim rozładowywanie samochodów z żywnością. SS-mani dostawali na śniadanie chleb, kostkę margaryny wraz z kiełbasą i innymi rodzajami wędlin o znacznie lepszej jakości niż więźniowie. Na obiad jedli przeważnie grochówkę na boczku z pajdą chleba, ale były też dni, kiedy dostawali dodatkowo kotlety mielone ${ }^{35}$. Więźniowie nie mogli rozlewać wachmanom zup, ponieważ mieli oni pretensje, że była źle nabierana i tym samym każdy dostawał różnej wielkości porcje.

Kuchnia dietetyczna w KL Stutthof w zasadzie nie istniała ${ }^{36}$. Pokarm dla chorych przeważnie nie różnił się niczym od zwykłego obozowego jedzenia, a zdarzało się, że jeden chleb dzielono pomiędzy 25 więźniów ${ }^{37}$. Według relacji Teresy Szczech (była więźniarka numer 90132) wyżywienie na rewirze wyglądało następująco: na śniadanie i kolacje mały kawałek chleba, a dodatkowo mikroskopijnej wielkości kostka margaryny oraz kawa. Z kolei na obiad chory prawie zawsze

${ }^{35}$ AMS, Relacje i Wspomnienia t. 17, relacja Teofilii Białowąs, s. 4.

36 Dla porównania w Auschwitz istniała kuchnia dietetyczna. Przygotowywano w niej ok. 3501 różnych pokarmów płynnych (co zaspokajało potrzeby 1/10 chorych): herbatę ziołową, kleik (dla więźniów chorych na biegunkę i pozostałe choroby przewodu pokarmowego) i zupę bezsolną z minimalną ilością mięsa i ziemniakami - dla osób cierpiących na schorzenia nerek. Chorzy więźniowie dostawali zupy przygotowywane z płatków owsianych, grysiku, kaszy, makaronu z dodatkiem sproszkowanego mleka. Wzbogacano je okruchami spleśniałego chleba i dla „urozmaicenia” dorzucano zanieczyszczone resztki żywności (zob. K. Okoniewska, dz. cyt.).

${ }^{37}$ Chodzi przede wszystkim o barak 21 , w którym przebywali więźniowie cierpiący na krwawą biegunkę. AMS, Relacje i Wspomnienia t. 5, relacja Czesława Majewskiego, s. 39 . 
otrzymywał kaszę manną lub zwykłą. Zdarzało się też, że mężczyźni przynosili na rewir jedzenie z kuchni esesmańskiej, np.: zupę grochową na boczku, jednak blokowa biła zarówno ich, jak i osoby, które odbierały jedzenie ${ }^{38}$. W pewnym okresie przyznano dla więźniów także ryż, który przyrządzano dla chorych na biegunkę. Najprawdopodobniej w 1943 r. zaczęto podawać mleko, którego otrzymywano średnio 50 litrów na 1000-1200 chorych $^{39}$. Mleko rozdzielał między chorych więźniów Julian Węgrzynowicz (nr obozowy 9230), który w swojej relacji zeznał: „Dawałem to mleko ludziom, którzy według mojej oceny zasługiwali najbardziej na ten kubek mleka. Robiłem to zgodnie ze swoi sumieniem" 40 .

Wszelkie efekty leczenia schorzeń gastrycznych były zniweczone właśnie przez typowe obozowe odżywianie. Biały chleb w ogóle nie był dostępny, zatem więźniowie otrzymujący do jedzenia czarny chleb czy kapuśniak często umierali. Z pomocą przychodzili więźniowie, którzy otrzymywali paczki z Czerwonego Krzyża, nadmiar jedzenia potajemnie oddawali chorym. Alfons Wojewski spisał w swoich wspomnieniach, że prosił o oficjalną zgodę na przekazywanie chorym jedzenia z paczek z Czerwonego Krzyża, jednak nie otrzymał go, SSmani woleli bowiem, by to jedzenie się zepsuło ${ }^{41}$.

\section{Kary za kradzież jedzenia}

Kradzież jedzenia była jednym z najczęściej popełnianych wykroczeń. Nie powinno to dziwić z racji okoliczności, kiedy to więźniowie zmagali się z ogromnym głodem każdego dnia. Jednak, jak wspominał w swojej relacji były więzień KL Stutthof Wiktor Ostrowski (były więzień numer 35 853), ,Ukraść bochenek chleba z zapasów nagromadzonych w piekarni, ukraść go spod rąk drania, który ten chleb sprzedaje, a nie przydziela go, ukraść ryzykując nawet życiem, a zwłaszcza ukraść nie dla siebie, a dla kolegów - to organizacja, przynosząca zadowolenie moralne, że nawet w tych warunkach triumfu zła i podłości - odruch ludzki istnieje, walczy i zwycięża"42.

Kary, jakie wymierzano za ów czyn, miały miejsce w każdym obozie koncentracyjnym i miały różny wymiar. Zapisywane jako meldu-

${ }^{38}$ AMS, Relacje i Wspomnienia t. 6, relacja Teresy Szczech, s. 211.

${ }^{39}$ AMS, Relacje i Wspomnienia t. 6, relacja Juliana Węgrzynowicza, s. 254.

40 Tamże.

${ }^{41}$ Maszynopis pracy doktorskiej Alfonsa Wojewskiego, Stan sanitarny i organizacja pomocy lekarskiej w obozie koncentracyjnym w Stutthof w latach 1943 do 1945, Poznań 1946, s. 32.

${ }^{42}$ AMS, Relacje i Wspomnienia t. 5, relacja Wiktora Ostrowskiego, s. 100. 
nek dzieliły się na kilka rodzajów, m.in.: kradzież żywności, oddalenie się z miejsca pracy, by kraść żywność, kradzież chleba, kradzież ziemniaków, próba ugotowania skradzionych ziemniaków, kradzież jarzyn, kradzież z paczek, kradzież w kantynie, kradzież przez funkcyjnych z porcji dziennej więźniów, kradzież i spożywanie alkoholu. Za kradzież żywności można było otrzymać 20 uderzeń kijem ${ }^{43}, 2$ dni aresztu $\mathrm{z}$ odjęciem pożywienia, odrzucano możliwość zwolnienia $\mathrm{z}$ obozu ${ }^{44}$.

Za kradzież chleba wyznaczono nawet do 8 dni w ciemnicy, a taką karę otrzymał więzień, którego przyłapano na okradaniu współwięźniów ciężko pracujących w cegielni i na prowadzeniu wymian za różnego typu usługi. Prócz ciemnicy dołożono także karę w postaci rzadziej otrzymywanego jedzenia. Nieszczęśnik otrzymywał chleb i wodę co czwarty dzień. Więźniowie otrzymywali też baty, mieli jednak sposoby, które sprawiały, że kara była nieco lżejsza: „Wiedząc, że zostanę ukarana, włożyłam pod sukienkę skrawki futra, tak że później nie czułam bicia"45.

Za kradzież ziemniaków groziły 3 dni $\operatorname{aresztu}^{46}, 3$ niedziele bez żadnego pożywienia ${ }^{47}$, minimum 10 uderzeń kijem, 25 batów w przypadku kradzieży łączonej, czyli np. ziemniaków i jarzyn, ewentualnie pojedyncze odjęcie obiadu wraz z karnymi ćwiczeniami. Dodatkowo np. za jedzenie buraka podczas pracy można było dostać 25 batów wraz z odjęciem obiadu na dwa dni ${ }^{48}$, z kolei za kradzież masła z paczki innego więźnia młody Rosjanin został położony mroźną zimą nago w długiej wannie, następnie był oblewany chłodną wodą oraz bity, aż do śmierci ${ }^{49}$.

Na powyższych przykładach można zauważyć, że podstawowym rodzajem kary w przypadku kradzieży żywności były uderzenia kijem, których liczba była zależna jedynie od SS-mana, który składał meldunek. Wielu więźniów zgodnie przyznało, że najdotkliwszą spośród wszystkich wymienionych kar było pozbawienie więźnia pokarmu lub obniżenie racji żywnościowej, co nieraz przyspieszało śmierć bądź było jej głównym powodem.

${ }^{43}$ Kozioł znajdował się za barakiem kuchni, a kara odbywała się w obecności wszystkich więźniów, na apelu (AMS, Relacje i Wspomnienia t. 6, relacja Cypriana Wosztala, s. 272).

${ }^{44}$ AMS, Akta Personalne, sygn. I III 50182 Stanisław Kisiel.

${ }^{45}$ AMS, Relacje i Wspomnienia t. 17, relacja Elżbiety Stremlau, s. 137.

${ }^{46}$ AMS, Akta Personalne, sygn. I III 47124 Józefa Kielan.

47 AMS, Akta Personalne, sygn. I III 17281 Piotr Wenda.

${ }^{48}$ AMS, Relacje i Wspomnienia t. 5, relacja Jana Strycharczyka, s. 254.

${ }^{49}$ AMS, Relacje i Wspomnienia t. 6, relacja Stefana Dudzińskiego, s. 4. 


\section{Wyżywienie podczas ewakuacji}

Ewakuacja z KL Stutthof odbywała się etapami i na dwa sposoby: lądowy i morski ${ }^{50}$. Przed ewakuacją więźniom rozdano na drogę chleb (ok. pół kilograma), pół kostki margaryny ${ }^{51}$, czasami odrobinę suszonego mięsa ${ }^{52}$ lub dwie kosteczki sera ${ }^{53}$. Więźniowie, którzy byli ewakuowani droga lądową, uzyskiwali chleb od mieszkańców wsi, przez które przechodzili. W zależności od SS-manów, którzy prowadzili daną kolumnę, można było taki chleb pobrać, jednak w większości przypadków więźniowie byli bici i odganiani od pokarmu. Były też sytuacje, że okoliczna ludność przekupywała SS-manów wódką ${ }^{54}$. Zdarzało się także, że podczas postoju mieszkańcy okolicznych wsi zwozili dla więźniów zupy, które były przyrządzone z tego, co zdaniem gotujących było pożywne, zatem można było znaleźć w posiłku m.in.: kawałki kiełbasy, drobiu i kostki sera ${ }^{55}$. SS-mani zabronili więźniom spożywać śnieg „w obawie przed przeziębieniem”56.

Więźniowie ulokowani w późniejszym czasie w małych obozach państwowej służby roboczej otrzymywali na tydzień np. ok. $200 \mathrm{~g}$ chleba, a prócz tego raz dziennie rzadką zupę z resztkami kartofli i koniny $^{57}$, a w sytuacji kiedy wyżywienie było bardzo skąpe, zdzierano korę z drzew i z niej gotowano zupę ${ }^{58}$, natomiast w sytuacjach kryzysowych dochodziło do wyjadania wnętrzności z zabitego konia ${ }^{59}$ : „Na początku przywieźli zdechłe konie i jedliśmy z nich rosół. Ludność przywoziła wóz ziemniaków, przyprowadzili jałówkę. Gdy przywieźli

${ }^{50}$ Wpływ na wydanie decyzji dotyczącej ewakuacji obozu miała bliskość frontu wschodniego. 25 stycznia 1945 r. na trasę ewakuacji wyszło 7 kolumn, liczących od 1100 do 1600 więźniów. Dalsze dwie kolumny opuściły obóz 26 stycznia 1945 r. Miejscem docelowym dla więźniów stały się obozy niemieckiej służby pracy. Do marca 1945 r. więźniowie przebywali w obozach ewakuacyjnych, gdzie warunki były jeszcze gorsze niż w obozie macierzystym. W wyniku głodu, chorób, rozstrzeliwania i uśmiercania zastrzykami z fenolu obozów tych nie przeżyło ok. 50\% więźniów (zob. J. Grabowska-Chałka, dz. cyt., s. 117). 25 i 27 kwietnia 1945 r. ewakuowano z obozu KL Stutthof drogą morską pozostałych przy życiu ok. 4400 więźniów. Zob. http://stutthof.org/node/173 [dostęp: 20.10.2019].

51 AMS, Relacje i Wspomnienia t. 6, relacja Henryka Stańczaka, s. 204.

52 AMS, Relacje i Wspomnienia t. 6, relacja Zbigniewa Raczkiewicza, s. 180.

${ }^{53}$ AMS, Relacje i Wspomnienia t. 14, relacja Jana Michała Langiewicza, s. 122.

${ }^{54}$ AMS, Relacje i Wspomnienia t. 12, relacja Anny Neubauer, s. 195.

55 AMS, Relacje i Wspomnienia t. 5, relacja Wiktora Ostrowskiego, s. 137.

56 AMS, Relacje i Wspomnienia t. 6, relacja Elżbiety Marcinkowskiej-Szucowej, s. 69.

57 AMS, Zbiory, Tłumaczenie dokumentów nadesłanych przez prokurature ZSRR dot. zbrodni popetnionych w KL Stutthof, Z-V-24, s. 91.

${ }_{58}$ AMS, Relacje i Wspomnienia t. 6, relacja Marii Kłosak-Reiter, s. 35.

${ }^{59}$ AMS, Relacje i Wspomnienia t. 14, relacja Jana Michała Langiewicza, s. 122. 
zdechłego konia rozpruwali go, gotowali nogi od kolan razem z kopytami i podkową w wiadrach od marmolady. Niektórzy więźniowie jedli wnętrzności" ${ }^{60}$.

Osadzeni, którzy nadal pozostali w obozie Stutthof, otrzymywali: na śniadanie ok. pół litra gorzkiej kawy, na obiad maksymalnie 3/4 litra zupy ze zgniłych buraków czerwonych lub brukwi, na kolację była kawa i ok. 3-4 ziemniaków gotowanych w łupinach, z czego trafiały się także nadgniłe ${ }^{61}$.

Osoby biorące udział w ewakuacjach morskich przebywały na barkach w wyjątkowo ciężkich warunkach. Ci, którzy nie mogli już wytrzymać bólu pragnienia, pili morską wodę i w ten sposób przypieczętowali swój $\operatorname{los}^{62}$, „Wypiłem już parę litrów wody morskiej, po której w gardle i brzuchu pali, jak ogniem" ${ }^{63}$.

Więźniowie, którzy mieli przy sobie kilka pokruszonych kawałków chleba, rozdrabniali go jeszcze bardziej, by na dłużej starczyło, i to $\mathrm{z}$ wielką ostrożnością, by nikt inny tego nie ujrzał ${ }^{64}$. Barki mieściły bardzo zróżnicowaną liczbę więźniów. Zdarzało się, że dla ok. 300 osób przeznaczono jedynie kilka bochenków chleba i kilka skrzynek wędzonych śledzi ${ }^{65}$, były też takie grupy, które miały nieco więcej szczęścia: „Każdy z nas otrzymał po pół bochenka świeżego chleba, a do tego po małej łyżce wazowej jakiejś zupy. Były to jakby zacierki ugotowane na wodzie, z ciemnej mąki. Jedni pili ją z własnych zardzewiałych, brudnych puszek [...], ci co nie mieli naczynia, otrzymywali blaszane kubki. Kto wypił zupę brał się w milczeniu za chleb. Byli jednak i tacy, którzy mimo okropnego głodu zjedli tylko część otrzymanej porcji, zachowując resztę na później. Zbawczy, zdawałoby się, chleb stał się przyczyną śmierci kilkunastu towarzyszy niedoli. Byli to ci, którzy od razu zjedli otrzymaną porcję gliniastego chleba, po którym nastąpiły silne skurcze żołądka, a później agonia wijących się z bólu wychudłych muzułmanów, którzy znaleźli wieczny spokój za burtą okrętu" 6 .

Podczas postojów w portach więźniowie wyruszali na poszukiwanie żywności. Niektórym udało dotrzeć się do piekarń, w których uzyskali pomoc nie tylko w postaci chleba, ale także ubrań. Na podstawie licz-

\footnotetext{
${ }^{60}$ AMS, Relacje i Wspomnienia t. 2, relacja Zygmunta Kwapisza, s. 9.

${ }^{61}$ AMS, Relacje i Wspomnienia t. 16, relacja Włodzimierza Gerunga, s. 31.

${ }^{62}$ AMS, Relacje i Wspomnienia t. 4, relacja Agnieszki Recław, s. 10.

${ }^{63}$ AMS, Relacje i Wspomnienia t. 2, relacja Bronisława Tuszkowskiego, t. 2, s. 84.

${ }^{64}$ AMS, Relacje i Wspomnienia t. 4, relacja Jerzego Nowickiego, s. 148.

${ }^{65}$ AMS, Relacje i Wspomnienia t. 4, relacja Agnieszki Recław, s. 15.

${ }^{66}$ AMS, Relacje i Wspomnienia t. 4, relacja Jerzego Nowickiego, s. 150.
} 
nych relacji wiadomo, że zdarzało się, że piekarze namawiali więźniów do ucieczki, tłumacząc, że Hitler nie żyje i lada dzień na te tereny wkroczy Armia Czerwona. Większość jednak nie zastosowała się do rady, gdyż każdy zostawił na barce przyjaciela czy drogiego kolegę, którego nie chciał zostawiaćc6 ${ }^{67}$. Nieraz podczas ewakuacji zdarzały się sytuacje, że wywiązywała się między osadzonymi walka o chleb, który wydała im piekarnia. SS-mani wówczas bili więźniów i strzelali do nich.

\section{Choroba głodowa i przemiany w organizmie}

Choroba głodowa to schorzenie objawiające się zaburzeniami czynności organizmu, wywołanymi wskutek niedożywienia. Choroba ta była powszechnym problemem występującym we wszystkich obozach koncentracyjnych, gdyż cierpiała na nią zdecydowana większość osadzonych. Towarzyszyła ona niemal wszystkim pozostałym schorzeniom i ukształtowała zarówno postać więźnia, jak i obraz jego życia w obozie.

W wyniku długotrwałego głodu dochodzi w organizmie do nieodwracalnych zmian. Początkową fazą jest stan niedoboru pokarmowego, który charakteryzuje się przede wszystkim chudnięciem, ponieważ organizm zużywa własne zapasy tłuszczu (tzw. kompensacja). Dla przykładu: przy rezerwie tłuszczowej wynoszącej $10 \mathrm{~kg}$ można przeżyć $40 \mathrm{dni}$, bez wysiłku fizycznego, zanim ów zapas zostanie wyczerpany ${ }^{68}$. Poza zmianami psychicznymi nie stwierdza się wyraźnych zmian chorobowych. Szybko zaczynają dominować objawy pobudzenia psychoruchowego wyrażające się stałym poszukiwaniem pożywienia. Towarzyszą temu natrętne myśli i sny o jedzeniu, a także iluzyjne postrzeganie jedzenia w miejscach, gdzie go nie było ${ }^{69}$. U chorego występuje osłabienie mięśni i uwydatnienie obrysów kości. Gałki oczne zapadają się w oczodołach. Głodzeni oddają mniej moczu, mają zwolnioną czynność jelit, występują zaparcia.

Podczas następnego etapu organizm wyczerpuje własne rezerwy odżywczo-energetyczne, a po ich wykorzystaniu zużywa białko tkanek (np. mięśni), powodując ich zniszczenie. Samotrawienie rozpoczyna się od największego magazynu rezerw, jakim jest wątroba. Pogarsza się stan skóry, staje się ona miękka, połyskującą, często wrażliwa na najmniejszy dotyk, a włosy matowieją i zaczynają wypadać. Masowo występowało także ich siwienie spowodowane niedoborem w odży-

${ }^{67}$ AMS, Relacje i Wspomnienia t. 4, relacja Agnieszki Recław, s. 14.

${ }^{68} \mathrm{H}$. Münch, dz. cyt., s. 79.

${ }^{69}$ Z. Ryn, S. Kłodziński, Psychopatologia głodu w obozie koncentracyjnym, „Przegląd Lekarski - Oświęcim,, 1985, nr 1, s. 41-55. 
wianiu ${ }^{70}$. Temperatura ciała spada do $36^{\circ} \mathrm{C}$, ciśnienie krwi obniża się i serce zaczyna pracować wolniej. Spada poziom hemoglobiny i obniżają się wartości czerwonych i białych krwinek ${ }^{71}$, więźniowie cierpią na anemię. Zmniejsza się stopień zakwaszenia żołądka oraz ilość wydzielanego soku żołądkowego. Klinicznymi objawami choroby głodowej są dodatkowo: obrzęki występujące najczęściej na kończynach dolnych $^{72}$ (w przypadku osób leżących występowały na twarzy i pośladkach, nieraz maskowały znaczny stopień wychudzenia ${ }^{73}$ ), zespół zmian skórnych oraz biegunka. Biegunka jedynie na początku miała wygląd kałowy, z czasem miała charakter wodnisto-śluzowy z domieszką krwi i ropy: „Chorzy na krwawą biegunkę przeważnie nie wstawali i załatwiali się pod siebie. Przy tej chorobie chory bez przerwy wydala krwawy, płynny kał. Dlatego też chorzy, którzy już nie wstawali, wydzierali tylną część spodni, aby wypróżniać się w startą słomę, która służyła za posłanie. [...] zwykle po paru dniach chory umierał. Po usunięciu zmarłego ta cuchnąca mierzwa służyła za legowisko dla następnego skazańca"74.

Badania wykonane w laboratoriach SS wykazały, że w próbkach kałowych wykryto strzępy błony śluzowej zstępnicy i odbytnicy, śluz, krwinki czerwone i białe. Ten rodzaj biegunki ustępował jedynie pod wpływem poprawy wyżywienia. Nie zmienia to jednak faktu, że więźniowie próbowali się z niej wyleczyć na wszelakie sposoby: w Auschwitz więźniowie dostawali tabletki węgla i tanalbinę ${ }^{75}$, jedli także zwęglone skórki chleba, a w Mauthausen i Stutthof prócz chleba osadzeni przygotowywali zwęgloną korę lub poddawali się bezwzględnej, trzydniowej głodówce. Jeden z byłych więźniów KL Stutthof Jakub Agaciński (numer 74 121) zrelacjonował, że w wyleczeniu z biegunki udział miał jego kolega, który otrzymał paczkę suszonych jagód i podzielił się z nim7 .

70 J. Kowalczykowa, Choroba głodowa w obozie koncentracyjnym w Oświęcimiu, „Przegląd Lekarski - Oświęcim” 1961, nr 1a, s. 59.

${ }^{71}$ W. Fejkiel, Szpital więźniarski w KL Auschwitz, Oświęcim 1994, s. 60-66.

${ }^{72}$ AMS, Relacje i Wspomnienia t. 5, relacja Jana Strycharczyka, s. 260. Najlepszym środkiem zaradczym byłoby podawanie dziennie litra mleka, wówczas obrzęki ustępują, jednak lekarz SS Heidel zawsze komentował to, mówiąc, że spowodowane to jest brakiem soli czy nieodpowiedniej jakości wodą. Nigdy nie przyznał, że to skutek braku prawidłowego odżywiania, a tym samym utraty cennego białka. Uważał, że obrzęki można zniwelować przez: gimnastykę, drożdże i różnego typu środki chemiczne (maszynopis pracy doktorskiej A. Wojewskiego, Stan sanitarny i organizacja pomocy lekarskiej w obozie koncentracyjnym w Stutthof w latach 1943 do 1945, Poznań 1946, s. 34).

73 J. Kowalczykowa, dz. cyt., s. 58.

${ }^{74}$ AMS, Relacje i Wspomnienia t. 5, relacja Czesława Majewskiego, s. 39-40.

${ }^{75}$ W. Fejkiel, dz. cyt., s. 66. Lek przeciwbiegunkowy - białczan taniny.

${ }^{76}$ AMS, Relacje i Wspomnienia t. 17, relacja Jakuba Agacińskiego, s. 173. 
Więzień tracił też odporność. Jeśli zachorował na chorobę zakaźną, wówczas miała ona inny przebieg z powodu anergii, czyli niezdolności organizmu do obrony. Taka osoba stawała się głównym źródłem zakażenia i poddawano ją „likwidacji”.

Ostatecznie następowało ogólne spowolnienie czynności psychicznych, intelektualnych i emocjonalnych. Zainteresowania koncentrowały się wokół przeżywanych dolegliwości somatycznych. Tok myślowy stawał się ociężały, występowały trudności w rozumieniu i zapamiętywaniu, pojawiało się zobojętnienie i rozpacz ${ }^{77}$.

\section{Przemiany psychiczne wynikające z choroby głodowej}

Nieco inne spojrzenie na rozwój choroby głodowej podał Stanisław Sterkowicz, były więzień KL Neuengamme. Na podstawie własnych doświadczeń i obserwacji współwięźniów podzielił stan popadania w chorobę na cztery etapy:

Etap pierwszy wstępny: w zależności od organizmu i stanu psychicznego więźnia trwał od dwóch do czterech miesięcy i rozpoczynał się w momencie aresztowania. Ogromny stres spowodowany nową sytuacją życiową i niepewność jutra niemal całkowicie odbierał apetyt. Szybko jednak wracała chęć walki o przetrwanie, a głód był coraz bardziej odczuwalny. Więzień starał się zdobyć pokarm, ale też rezygnował z produktów, które nie nadawały się już do spożycia. Często rozmawiał o jedzeniu i długo dyskutował z pozostałymi współwięźniami o tym, co na wolności było najsmaczniejsze. Zaczął zjadać na zapas, co miało być profilaktyką niepewnej przyszłości. Reasumując, był to moment, w którym człowiek nie upadlał się, by zdobyć jedzenie.

Etap drugi prostracja: trwał od jednego do trzech miesięcy. W oczy rzuca się ubytek wagi i utrata sił fizycznych: „Najpierw, rzecz zrozumiała, zniknął tłuszcz. Potem bez wyraźnej granicy znikały mięśnie i to na początek wielkie. Typowa sylwetka mieszkańca obozu charakteryzowała się płaską formą pośladków. Również i poruszanie się odbiegało od utartych typów. Zwłaszcza bieg był jakby sztywny, gdyż przeznaczone do tego celu mięśnie uległy zanikowi. Włosy stawały się cienkie i nie rosły [...]"78.

W początkowej fazie głodu ludzie potrafili jeszcze zachować określone normy etyczne, jednak w następnym okresie wszystkie hamulce zaczęły zawodzić. Więzień stawał się pobudzony i drażliwy, koncentrował się na zdobywaniu pożywienia, przestawał odrzucać jedzenie

77 Z. Ryn, S. Kłodziński, dz. cyt., s. 41-55.

${ }^{78}$ AMS, Relacje i Wspomnienia t. 11, relacja Lecha Duszyńskiego, s. 33. 
obozowe: „Oczy tych ludzi zawsze były skierowane na ziemię, gdyż tam mogli znaleźć coś do jedzenia. Rozwarte źrenice oczom tym nadawały specjalnego blasku, a ich wieczna ruchliwość sprawiała niesamowite wrażenie" 79 .

$\mathrm{Na}$ tym etapie nie gardzono spleśniałym chlebem. Marzeniem był kawałek mięsa i ziemniaka w zupie. Jeden drugiemu zarzucał pobieranie większych porcji jadła, a w zupie sąsiada widział mniej wody i więcej dodatków. Istniało pragnienie pozyskania pełnego żołądka, dochodziło do wymiany bardziej wartościowego chleba na kilka misek cienkiej zupy. Głodzeni gromadzili się koło kuchni, magazynów, śmietników albo zazdrośnie otaczali więźniów spożywających pokarm, spoglądając zawistnie i wyczekując rzadko zdarzającej się okazji wylizania menażki lub beczki po zupie: „Znałem przypadki, kiedy wynędzniali ludzie, pracując $\mathrm{w}$ charakterze pomocniczym przy krematorium, wkładali stare, na pół zgniłe jarzyny do pieca, w którym smażyły się zwłoki ludzkie, rozsiewające w tym okresie przyjemny zapach pieczonego mięsa, aby ociekający z nich tłuszcz okrasił zgniłe i jałowe pożywienie" 80 .

Duma i godność człowieka stopniowo zanikała, ludzie byli w stanie zrobić wszystko za kawałek chleba.

Etap trzeci marazm: trwał od trzech do sześciu tygodni. Więzień poszukiwał pomocy $\mathrm{u}$ innych, zbierał odpadki i zjadał wszystko: zgniłe warzywa, zgniłe mięso, pił trujące oleje maszynowe. Stał się kryplem $^{81}$, muzułmanem ${ }^{82}$, gamlem ${ }^{83}$. Był obojętny na wszystko, co go otaczało, nie lękał się śmierci, a nieraz stanowiła ona ,jedyne rozwiązanie przeszłości” 84 .

Etap czwarty końcowy: trwał do trzech tygodni. Okres ten charakteryzował brak apetytu i postępujące zobojętnienie. Więzień umierał najczęściej podczas wykonywania czynności obozowych, np. podczas marszu, będąc wspartym o kolegę, czy od uderzenia kolby wachmana ${ }^{85}$.

Ludzie wygłodzeni prowadzili charakterystyczne rozmowy. Obiecywali sobie, że po powrocie do domu będą zjadali na raz kilka misek gęstego posiłku, po kilka bochenków chleba z masłem i boczkiem, ma-

\footnotetext{
${ }^{79}$ Tamże.

${ }^{80}$ Tamże, s. 35.

${ }^{81}$ Powszechne określenie w Stutthof na osobę cierpiącą na chorobę głodową.

${ }^{82}$ Powszechne określenie w Auschwitz na osobę cierpiącą na chorobę głodową.

${ }^{83}$ Powszechne określenie w KL Lublin (Majdanek) na osobę cierpiącą na chorobę głodową.

${ }^{84}$ AMS, Relacje i Wspomnienia t. 25, relacja Władysława Kraski, s. 75.

${ }^{85}$ S. Sterkowicz, Uwagi o obozowym wyniszczeniu głodowym, „Przegląd Lekarski - Oświęcim” 1971, nr 1, s. 19-22.
} 
rzyli o wypiciu szklanki mleka lub herbaty ${ }^{86}$. Kobiety urządzały w KL Stutthof „kursy gotowania”, które tak naprawdę polegały na rozmowie o przygotowywaniu potraw i spisywaniu przeróżnych przepisów kulinarnych: „Taki przepis po części zaspokajał głód. Łykając ślinę marzyłyśmy, że kiedy wrócimy do domu to naszym najbliższym sporządzimy te wszystkie smakowite potrawy" ${ }^{87}$.

Całodzienne udręki wywołane myśleniem i rozmowami o jedzeniu dopełniały się w nocnych, kulinarnych marzeniach sennych. Do najczęstszych obrazów należał widok wypieczonego chleba i miski wypełnione parującymi ziemniakami ${ }^{88}$. Pojawiały się też potrawy różnorodne i obfite, jednak bardzo sporadycznie. Jedni śnili o tym, że spożywają upragniony pokarm, a drugim nigdy nie udało się go nawet dotknąć, gdyż zawsze stała na drodze jakaś przeszkoda. Temat jedzenia stał się także motywem przewodnim wierszy:

„Pajdeczko moja droga - co żeś taka mała?

Z której strony cię zacząć? Jesteś doskonała, Jesteś tak znakomita, jesteś taka cienka, Że, gdy cię otrzymuję, to aż drży mi ręka, By cię nie złamać czasem, nie zgiąć, nie uszkodzić...

Starają cię tu wszyscy godnie przozdobić, Byś, chociaż mała, wątła, poszła nam na zdrowie, A pióro nie opisze, słowo nie wypowie

Tych cudów, które kładą na twe miękkie łono...

Pierwszy - cud marmolady, ale trzeba pono

Mieć silne okulary, aby ją zobaczyć ...

Wiele ta mała ilość musi dla nas znaczyć

Czasem jest margaryna w niewielkiej ilości -

Cud to nie jest, jest jednak szczyt doskonałości.

Raz na tydzień jest serek - zapach w nozdrzach kręci,

A w sobotę kiełbasa czy kiszka nas nęci

Pajdeczko moja droga! [...]"89

Władysław Fejkiel, były lekarz-więzień KL Auschwitz, przeprowadził analizę wpływu różnych czynników na wytrzymałość i szybkość pojawiania się choroby głodowej. Jego zdaniem największe znaczenie miały:

\footnotetext{
${ }^{86}$ AMS, Relacje i Wspomnienia t. 12, relacja Antoniego Dulskiego, s. 246.

87 AMS, Relacje i Wspomnienia t. 18, relacja Heleny Jarockiej, s. 79.

${ }_{88}$ M. Susułowska, Próba interpretacji treści snów były więźniów obozów koncentracyjnych, „Przegląd Lekarski - Oświęcim” 1976, 33 nr 1, s. 14.

${ }^{89}$ AMS, Relacje i Wspomnienia t. 5, relacja Wiktora Ostrowskiego, s. 60.
} 
1) wiek: w warunkach obozowych najbardziej wytrzymali byli ludzie w wieku między 18. a 30. rokiem życia. Zarówno u osób powyżej, jak i poniżej tej granicy znacznie szybciej było widać objawy głodzenia;

2) tryb życia prowadzony na wolności: robotnicy, którzy pracowali na wolnym powietrzu, często w złych warunkach atmosferycznych, najdłużej opierali się skutkom głodu. Źle znosiły głód osoby pracujące umysłowo, a najgorzej chłopi;

3) konstytucja osobnicza: najdłużej wytrwali w głodzie ludzie szczupli, niewysocy, z kolei więźniowie wysocy o dużej masie ciała najgorzej wytrzymywali głód i życie obozowe;

4) czas pobytu w więzieniu: szybciej umierali ludzie po dłuższym okresie pobytu w więzieniach ${ }^{90}$.

Julian Węgrzynowicz, były więzień KL Stutthof, w swojej relacji podsumował, że obóz najłatwiej było przetrwać Polakom, ponieważ oprócz tego, że posiadali zaplecze rodaków i rodzin wysyłających paczki żywnościowe, to jako najbliżsi sąsiedzi Niemców potrafili przewidzieć ich reakcje na różne sytuacje. Dodatkowo spora część więźniów polskich znała język niemiecki lub szybko się go uczyła. Podkreślił, że inteligencja była znacznie bardziej prześladowana niż pozostałe grupy więźniów, zwłaszcza w początkowym okresie istnienia KL Stutthof: „Im stał niżej intelektualnie, tym większy miał spokój. Inteligencja szybko załamywała się psychicznie" ${ }^{\text {91 }}$.

Najwięcej przetrwało rzemieślników, którzy byli Niemcom bardzo potrzebni. Była też grupa osób wykształconych, która podawała się za rzemieślników i tym sposobem przetrwała obóz, bo łatwiej było przeżyć, kiedy miało się przydatny zawód.

Reasumując, racje żywnościowe w obozach koncentracyjnych były rozpisane w taki sposób, by więzień mógł w nich funkcjonować najdłużej przez okres trzech miesięcy. Maksymalna wartość odżywcza w KL Stutthof wynosiła $1300 \mathrm{kcal}$, z kolei dla więźniów pochodzenia żydowskiego wielokrotnie spadała poniżej $1000 \mathrm{kcal}$, a w sytuacjach krytycznych (przełom 1944/1945 r.) Żydzi w ogóle nie otrzymywali pokarmu. Jedynym źródłem tłuszczu była margaryna, białka - mało wartościowe mięso, z kolei warzywa i ziemniaki (wydawane w największej ilości) były zepsute.

Głód całkowicie ukształtował życie osadzonego w obozie. Wyzwalał nieznane wcześniej uczucia i sprawiał, że ludzie posuwali się do

${ }^{90}$ W. Fejkiel, dz. cyt., s. 72-74.

${ }^{91}$ AMS, Relacje i Wspomnienia t. 6, relacja Juliana Węgrzynowicza, s. 256. 
wszystkiego, by zdobyć pożywienie: bito się o kromkę chleba po śmierci kolegi, wyrywano ją innemu więźniowi, posuwano się nawet do spożywania mięsa nieżyjących ludzi. Za każdą próbę zdobycia pokarmu groziła kara, a najsurowszą było pozbawienie wyżywienia lub obniżenie racji żywnościowej, co nieraz doprowadzało do śmierci więźnia. By podwyższyć wydajność pracy osadzonych, wprowadzono bony, za które można było kupić dodatkowe produkty do spożycia, takie jak buraki w occie, surowe warzywa, kiszoną kapustę i chleb. W skali całego obozu nie rozwiązywało to jednak nawet częściowo problemu położenia więźniów.

U wygłodzonego więźnia szybko zaczęła dominować chęć stałego poszukiwania pożywienia, natrętne myśli i sny o pożywieniu oraz iluzyjne postrzeganie jedzenia w miejscach, gdzie go nie było. Osadzeni prowadzili charakterystyczne rozmowy, a temat jedzenia stał się także motywem przewodnim wierszy.

Warto też podkreślić, że na podstawie obserwacji więźniowie wyciągnęli wnioski co do wytrwałości na warunki panujące w obozie. Osobami najbardziej wytrzymałymi na pracę, jednak najmniej odpornymi na głód, byli ludzie w wieku między 18. a 30. rokiem życia. Pracownicy fizyczni, którzy pracowali na wolności w niesprzyjających warunkach atmosferycznych, najdłużej opierali się skutkom głodu, z kolei najgorzej znosiły głód osoby pracujące umysłowo i chłopi. Najdłużej wytrwali w głodzie ludzie szczupli, z kolei więźniowie o dużej masie ciała najkrócej.

Skutki niedożywienia nieuchronnie wyniszczały organizm, doprowadzając do powolnej śmierci. Ci, którzy przeżyli obóz, przez wiele lat wracali do zdrowia, większość byłych więźniów odczuwała skutki pobytu w KL do końca życia.

\section{Bibliografia}

\section{Źródła archiwalne:}

AMS (Archiwum Muzeum Stutthof), Relacje t. 2,

AMS, Relacje t. 4, AMS, Relacje t. 5, AMS, Relacje t. 6, AMS, Relacje t. 11, AMS, Relacje t. 14, AMS, Relacje t. 16, AMS, Relacje t. 17, AMS, Relacje t. 18, 
AMS, Relacje t. 25.

AMS, Lagerarzt, Wykaz więźniów z podaniem wagi ciała w dniu przybycia do obozu oraz w dniu 24.11.1942 r., I-VB-12.

AMS, Zbiory, Ttumaczenie dokumentów nadesłanych przez prokurature ZSRR dot. zbrodni popetnionych w KL Stutthof, sygn. Z-V-24.

AMS, Verwaltung, Zaopatrzenie kuchni w środki żywnościowe. Korespondencja, rozliczenia, sygn. I-IVI-2.

\section{Artykuły i publikacje:}

Fejkiel W., Szpital więźniarski w Auschwitz, Oświęcim 1994.

Kowalczykowa J., Choroba głodowa $w$ obozie koncentracyjnym w Oświęcimiu, „Przegląd Lekarski - Oświęcim” 1961, nr 1a.

Kiwała J., Kuchnia dietetyczna w szpitalu obozu koncentracyjnego w Oświęcimiu, „Przegląd Lekarski - Oświęcim” 1964, nr 1.

Maszynopis pracy doktorskiej A. Wojewskiego, Stan sanitarny i organizacja pomocy lekarskiej $w$ obozie koncentracyjnym $w$ Stutthof w latach 1943 do 1945, Poznań 1946.

Münch H., Gtód i czas przeżycia w obozie oświęcimskim, „Przegląd Lekarski - Oświęcim” 1967, nr 1.

Okoniewska K., Zbrodniczy medycy. Lekarze z Auschwitz, Łódź 2017.

Orski M., Niewolnicza praca więźniów obozu koncentracyjnego Stutthof w latach 1939-1945. Organizacja pracy i metody eksploatacji sity roboczej, Gdańsk 1999.

Ryn Z., Kłodziński S., Psychopatologia głodu w obozie koncentracyjnym, „Przegląd Lekarski - Oświęcim” 1985, nr 1.

Sterkowicz S., Uwagi o obozowym wyniszczeniu głodowym, „Przegląd Lekarski - Oświęcim” 1971, nr 1. 